\title{
Hepatoprotective Effect of Eclipta Alba on Membrane Marker Enzymes against Paracetamol Induced Liver Damage
}

\author{
A. INDHULEKA and M. JEYARAJ* \\ Department of Chemistry, Sri Krishna College of Engineering and Technology, Coimbatore, \\ TamilNadu, 641 008, India. \\ ${ }^{*}$ Corresponding author E-mail: jeyaraja100@gmail.com \\ http://dx.doi.org/10.13005/ojc/350343
}

(Received: June 10, 2019; Accepted: June 21, 2019)

\begin{abstract}
The study is an attempt to explore the efficacy of Eclipta alba as a hepatoprotectant against paracetamol induced hepatotoxicity. Paracetamol was used to induce toxicity. The animals were grouped into four along with control. Analyses of phytochemical constituents of the plant and biochemical parameters in the serum of the experimental animals along with membrane marker enzymes were carried out. The results proved that E.alba is a good hepatoprotective agent.
\end{abstract}

Keywords: Hepatoprotective agent, Liver damage, Marker enzymes, Eclipta alba, Paracetamol.

\section{INTRODUCTION}

Liver an important organ actively involved in many metabolic functions is the frequent target of a number of toxicants. Liver diseases, which are still a global health problem, may be classified as acute or chronic hepatitis (inflammatory liver diseases), hepatosis (non-inflammatory diseases) and cirrhosis (degenerative disorder resulting in liver fibrosis). Unfortunately, treatments of choice for liver diseases are controversial because conventional or synthetic drugs for the treatment of these diseases are insufficient and sometimes cause serious side effects. $^{1}$

Liver is the organ which protects us from harmful drugs and chemicals by performing its physiological functions. Hepatitis and Jaundice are the two main hepatic ailments that accounts for increased death rate ${ }^{2}$. Liver has a pivotal role in regulation of physiological processes. It is involved in several vital functions such as metabolism, secretion and storage. Furthermore, detoxification of a variety of drugs and xenobiotics occur in liver. The bile secreted by the liver has an important role in digestion among other functions. Liver diseases, which are considered the most serious ailments, are mainly caused by toxic chemicals (certain antibiotics, chemotherapeutics, peroxidised oil, aflatoxin, carbon-tetrachloride, chlorinated hydrocarbons, etc.), excess consumption of alcohol, infections and autoimmune disorder. Most of the hepatotoxic chemicals damage liver cells mainly by inducing lipid peroxidation and other oxidative damages. ${ }^{3}$

This is an Open Access article licensed under a Creative Commons license: Attribution 4.0 International (CC- BY). Published by Oriental Scientific Publishing Company @ 2018

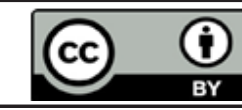


Many of the currently available drugs were derived either directly or indirectly from medicinal plants. Recent interest in natural therapies and alternative medicines has made researchers pay attention to traditional herbal medicine. In the past decade, attention has been centered on scientific evaluation of traditional drugs with plant origin for the treatment of various diseases. Due to their effectiveness, with presumably minimal side effects in terms of treatment as well as relatively low costs, herbal drugs are widely prescribed, even when their biologically active constituents are not completely identified. ${ }^{4,5}$

Eclipta. alba, commonly known as false daisy or bhringraj is a plant belonging to the family asteraceae (locally it is also called as Karisalankanni). The plants have well developed cylindrical greyish roots. Floral heads are 6 to $8 \mathrm{~mm}$ in diameter, solitary florets white; achene compressed and narrowly winged. It is a moisture loving creeping herb. Generally, found on road sides and wastelands throughout India. The plant is bitter, hot in taste and used in Ayurveda and Siddha for the treatment of vadha and kappa imbalances. The plant has been reported to contain phytosterol, $\beta$-amyrin, triterpenes and flavones ${ }^{6}$. Generally, the leaf extract of $E$. alba is a powerful tonic for liver diseases and especially good for hair growth and colour. Based on all these facts, the present study was carried out to analyse the phytochemical constituents in ethanol, methanol and chloroform extracts of E.alba plant and to ascertain the hepatoprotective effect in paracetamol intoxicated animal models through studying their biochemical parameters and levels of hepatic membrane marker enzymes.

\section{MATERIALS AND METHODS}

The various experimental protocols followed for the study are given below.

\section{Preparation of the plant extract}

Eclipta alba plants were cleaned and sliced into thin slices, washed with $10 \%$ saline, shade dried and powdered. The powder was mixed with water (150 mg/kg) and fed to the rats continuously for 7 days (twice a day).

\section{Phytochemical Analysis}

Qualitative analysis of some biochemical parameters in plants were carried out. Identification of alkaloids, flavonoids, tannins, saponins, phenols, glycosides and steroids was done according to the standard methods ${ }^{7}$.

\section{In vivo studies}

The Wister strain of albino rats $(150-200 \mathrm{~g})$ obtained from veterinary medical college Mannuthy, Kerala was used for the experimental studies. Animals were acclimated in large spacious cage condition for 30 days. They were given food and water during the course of the experiments. The animal room was ventilated well. The temperature remained between $20^{\circ} \mathrm{C}$ to $30^{\circ} \mathrm{C}$. The animals had wakeful and sleep period during day and night time. The commercial feed purchased from various industries in Coimbatore was served to the animals.

The experimental setup is as follows: Rats were divided into 4 groups comprising of five animals in each group.

\begin{tabular}{cl}
\hline Group & Experimental Set up \\
\hline I & Served as normal control rats \\
II & Toxicity induced with paracetamol $1 \mathrm{~g} \mathrm{~kg}^{-1}$ body \\
& weight (150 mg twice a day) up to 7 days \\
III & $\begin{array}{l}\text { Induction of paracetamol liver damage followed by } \\
10 \% \text { ethanol extract of Eclipta alba orally for } 7 \\
\end{array}$ \\
IV & $\begin{array}{l}\text { days twice a day } \\
\text { for } 7 \text { days twice a day }\end{array}$ \\
&
\end{tabular}

Paracetamol was selected to cause liver toxicity; $150 \mathrm{mg}$ of paracetamol induced orally twice a day up to 7 days. At the end of the experimental period, the animals were sacrificed by the cervical decapitation method. The blood was carefully collected by pumping the heart after the rat was killed. From the collected blood, the serum was separated by centrifugation. After the rats were sacrificed, the body was cut ventrally and the liver was removed and washed with ice cold saline and their weights were recorded. Biochemical parameters namely protein, cholesterol, urea, creatinine, alkaline phosphatase, acid phosphatase and 5 '-nucleotidase were estimated by following international procedures ${ }^{8}$ (Table 1 ). 
Table 1: Analyzed Biochemical parameters and Analytical Methods Employed

\begin{tabular}{ccc}
\hline S. No & Biochemical parameters & Methods \\
\hline 1 & Protein & Lowry's Method \\
2 & Cholesterol & Zak's Method \\
3 & Urea & Varley Method \\
4 & Creatinine & Jaffer's Reaction \\
5 & Alkaline phosphatase & King and Armstrong Method \\
6 & Acid phosphatase & King and Armstrong Method \\
7 & 5'-Nucleotidase & Campbell Method \\
\hline
\end{tabular}

\section{RESULTS AND DISCUSSION}

The result of phytochemical screening of Eclipta alba collected in Table 2 shows the main constituents responsible for the therapeutic value of the medicinal plant. They also contribute to the analgesic, diuretic and other biological activities and are most active against human pathogens. For ethanolic extract, all tests were positive. In chloroform extract, the Fehling's test for reducing sugar and the test for flavonoids were positive. All other tests were negative. In methanolic extract, test for tannins and cardiac glycosides were found negative and the rest were positive.

Table 2: Preliminary Phytochemical Screening of the Powder of Eclipta alba

\begin{tabular}{ccccc}
\hline S. No & Test & $\begin{array}{c}\text { Ethanolic } \\
\text { Extract }\end{array}$ & Chloroform & Methanol \\
\hline & & + & + & + \\
1 & $\begin{array}{c}\text { Fehling's Test } \\
\text { (for reducing sugar) }\end{array}$ & & & \\
2 & Flavonoids & + & + & + \\
3 & Saponins & + & - & + \\
4 & Alkaloids & + & - & + \\
5 & Tannins & + & - & + \\
6 & Glycosides & + & - & + \\
7 & Proteins & + & - & + \\
8 & Phenols & + & - & + \\
9 & Steroids & - & - & - \\
\hline
\end{tabular}

\section{Total Protein}

The estimated levels of total protein in serum significantly denote its impairment in the damage (Table 3). Total protein level seems to be increased in group II $(\mathrm{P}<0.01$ level of significance) when compared with group I. At the same time, it was insignificant in group III. Its level in group IV $(\mathrm{P}<0.05$ level of significance) has retained to incurred administration of Eclipta alba. It showed a significant decrease in levels of group IV $(P<0.05$ level of significance) when compared with group II. The results suggest that paracetamol administration for a week followed by Eclipta alba treatment restored the tissue damage, which proved the toxicity eliminating effect of Eclipta alba.

\section{Serum Cholesterol}

The biochemical parameter cholesterol registered a significant rise in serum of paracetamol treated rats (group II) as compared to the normal control group. The cholesterol levels were found to recover to near normal in Eclipta alba treated animals Fig. 1 .The mathematical calculation of the mean $\pm S D$ values shows the percentage of significance, which wasanalyzedby analysis of variance (ANOVA) and was found to be significant at $1 \%{ }^{9,10}$. The restoration of the liver function in Eclipta alba treated group (group III) reveals that the plant selected has a potential to regenerate the liver hepatocytes due to its hepatoprotective effect.

\section{Serum Urea}

Figure 2 represents the mean $\pm S D$ values of urea in paracetamol intoxicated (group II) and experimental groups. The marked elevation in the level of urea in group II represents the altered liver metabolic functions. The damage initiated by the toxicant (paracetamol) in group II (paracetamol intoxicant) animals shows direct potential toxicity induced in the liver. The elevated level of serum urea may be due to the damage of cell membranes leading to an abnormality in metabolism of urea by the liver. On treatment with the plant extract, group III animals showed a very positive sign of decrease in the serum urea level, which reaches the near normal value when compared to the control group (group I). Similar results were observed in pretreated group of (group IV) animals, which substantiate that the plant selected has got hepatoprotective property.

\section{Serum Creatinine}

The level of serum creatinine in paracetamol induced and experimental groups are represented in Table 3. Serum creatinine level of paracetamol intoxicated group (group II) showed a drastic elevation when compared to the control group. While on treatment with the plant extract, group III animals showed remarkable restoration in the level of serum creatinine. Similar decrease was noted in pretreated group. All the data documented by the present findings are in accordance with the results of Palanivel et al., ${ }^{11}$. 
Table 3: Total Protein, Creatinine, Cholesterol and Urea Level in Serum of Paracetamol Induced Toxicity in Experimental Groups of Animals

\begin{tabular}{ccccc}
\hline Test & Group I & Group II & Group III & Group IV \\
\hline Total protein & $5.10 \pm 0.180$ & $6.7 \pm 0.213 a^{\star *}$ & $4.9 \pm 0.219 a n s$ & $5.5 \pm 0.198 b^{*}$ \\
Creatinine & $1.83 \pm 0.007 a^{\star *}$ & $4.15 \pm 0.001$ & $2.45 \pm 0.002 b^{\star *}$ & $1.94 \pm 0.006 c^{\star *}$ \\
Cholesterol & $70 \pm 0.05 a^{\star *}$ & $109 \pm 010$ & $92.89 \pm 0.06 b^{\star *}$ & $70 \pm 0.10 c^{\star *}$ \\
Urea & $32.31 \pm 0.08 a^{\star *}$ & $62.64 \pm 0.02$ & $38.24 \pm 0.07 b^{\star *}$ & $32.87 \pm 0.06 c^{\star *}$ \\
\hline
\end{tabular}

Values are mean + SD $(n=5)$ statistical comparisons a, group II and group III with group | b, group IV with group ||

Elevated levels of serum creatinine of group II animals (paracetamol intoxicant) show the toxicity initiated by the paracetamol leads to severe liver damage, which in turn altered the normal metabolic status of liver. The restoration level of creatinine in Eclipta alba treated group (group III) exemplifies the hepatoprotective effect possessed by the plant and holds prospect as a powerful and safe hepatoprotective agent.

\section{Membrane bound enzymes}

The increased levels of membrane bound enzymes like alkaline phosphatase (ALP), acid phosphatase (ACP) and 5'-nucleotidase (NT) significantly and predominantly denote their impairment causing liver damage. As per Table 4, ALP activity seems to be significantly increased in group II when compared to group I. The enzyme activity seems to be non-significant in group III.

Results of serum biochemical assay elaborate the evaluation of selected hepatic enzyme activity providing information of liver cells after absorbing various drugs. Increase in the activity of serum ACP indicates severe injury to hepatic plasma membrane. These enzymes are localized in the membranes of hepatocytes. Due to hepatocellular injury to lysosomal membrane, leakage of enzymes occurs followed by cell destruction ${ }^{12}$.

Table 4: Activities of Liver Marker Enzymes in Experimental Rats

\begin{tabular}{|c|c|c|c|c|}
\hline Test & Group I & Group II & Group III & Group IV \\
\hline ALP & $19.47 \pm 0.613$ & $44.09 \pm 0.620 \mathrm{a}^{\star *}$ & $19.11 \pm 0.501$ ans & $27.7 \pm 0.609 b^{\star *}$ \\
\hline $\mathrm{ACP}$ & $17.46 \pm 0.402$ & $52.58 \pm 0.605 a^{* *}$ & $17.36 \pm 0.400$ ans & $29.62 \pm 0.618 b^{\star *}$ \\
\hline $5^{\prime} N T$ & $5.65 \pm 0.201$ & $13.046 \pm 0.211 \mathrm{a}^{\star \star}$ & $6.8 \pm 0.171$ ans & $10.39 \pm 0.10 b^{\star \star}$ \\
\hline
\end{tabular}

Values are mean $+S D(n=5)$ statistical comparisons a, group II and group III with group I b, group IV with group II (a, b, c, ${ }^{*},{ }^{* *}=$ Significance level in ANOVA, ns-not significant)

The level of liver marker enzyme $5^{\prime}-\mathrm{NT}$ is also presented in Table 4. On treatment with the plant extract, the animals showed a considerable decline, providing a positive effect posted by the plant in restoring the liver function. Pretreated animals of group IV showed a similar level of the enzyme when compared with the control. The results go in accordance with a similar work reported by Manda and Bishaye ${ }^{13}$.

Paracetamol induction resulted in the substantial increase in the activity of $5^{\prime}-\mathrm{NT}$ in liver, which indicates severe damage of hepatic membrane. A decrease in the activity of this enzyme in Eclipta alba extract treated groups is indicative of extract-mediated reversal of paracetamol induced cholestatic changes in the rat liver.

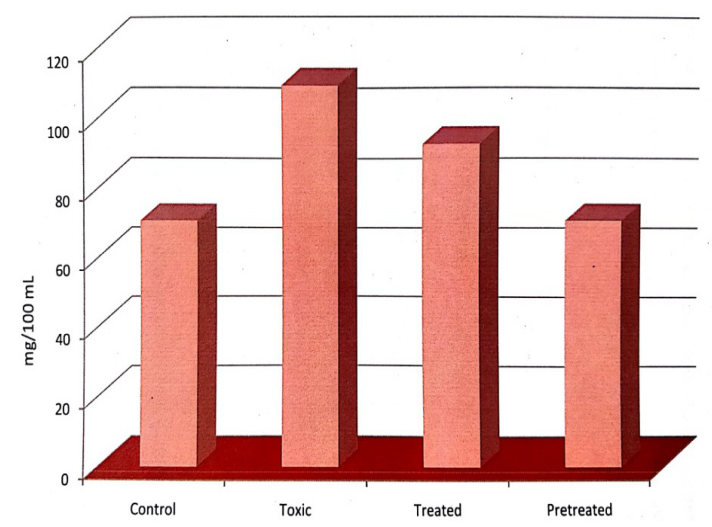

Fig. 1. Levels of Serum Cholesterol in Paracetamol Induced Toxicity in Experimental Groups of Animals 


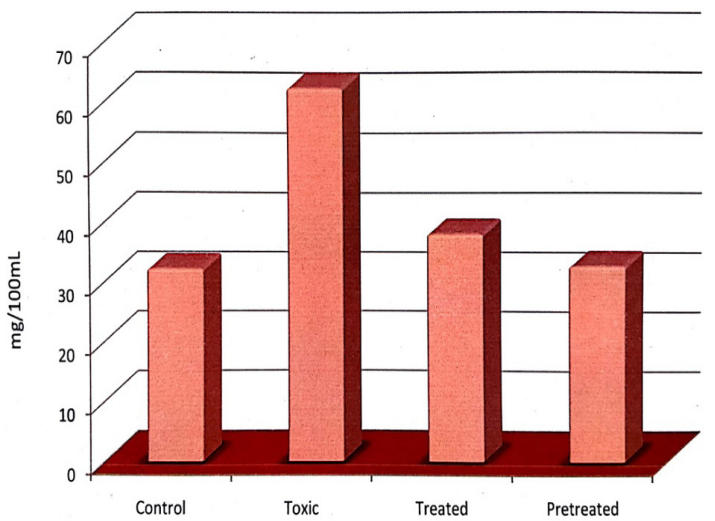

Fig. 2. Levels of Serum Urea in Paracetamol Induced Toxicity in Experimental Groups of Animals

\section{CONCLUSION}

In the present study on increase in serum enzymes ALP, ACP \& 5'NT in paracetamol induced hepatotoxic rats indicated the hepatic necrosis. Treatment with $E$. alba normalized the enzyme level in the treated group. The level of total protein is increased. Treatment with E. alba normalized the severity in the treated group. A considerable decease of urea in serum and increase of cholesterol have occurred in paracetamol induced rats, which are normalized by treatment with E. alba. Hence the role of $E$. alba as a hepatoprotective agent in reducing the hepatotoxicity has been proved effective in reducing the side effects. To find new pure compounds as drugs, the ethnopharmacological studies on herbal drugs should not be restricted and it should be extended to the isolation/formulation of active fractions/extracts, which could show the way for effective drugs. Since, no individual drug can cure all types of liver diseases, proper formulations have to be identified by different clinical trials. All these trials have to be governed by safety and efficacy standards.

\section{ACKNOWLEDGEMENT}

The authors are greatly thankful to Mrs. S. Malarvizhi, Chair Person and Managing Trustee, Sri Krishna Group of Institutions, Coimbatore for irrecoverable support and providing the research facilities. Wish to place on record their gratitude to the Institution which supports research in all ways.

\section{Conflict of interest}

There is no any conflict of interest.

\section{REFERENCES}

1. Hari Kumar, C.; Ramesh, A.; Suresh Kumar, J. N.; Mohammed Ishaq, B. Int. J Pharm. Sci. Res., 2011, 2, 501-515.

2. Pangs, Xin, X.; Stpierve, M.V, Ann. Rev. Pharmacol. Toxicol., 1992, 32, 625-626.

3. Smuckler, E. A. Fed Proc., 1975, 34, 2038-2044.

4. Majid, A. S.; Najme, K.F.; Nafiseh, A.; Ali, F.; Ebrahim, A. A, Mahmoud, R. K. Asian Pac. J. Trop. Biomed., 2015, 5, 146-157.

5. Levy, C.; Seeff, L. D.; Lindor, K. D. Use of herbal supplements for chronic liver disease, Clin. Gastroenterol. Hepato., 2004, 2, 947-956.

6. Jadhav, V.M.;Thorat, R. M.; Kadam, V.J.; Sathe, N. S. J. Pharm. Res., 2009, 2, 1236-1241.

7. Harbone, J. B. Phytochemical methods-a guide to modern technique of plant analysis, $2^{\text {nd }} \mathrm{edn}$, (Chapman and Hall, New York)., 1984, 85-87.

8. Lowry, J. H.; Rosenbrough, R. N.; Farr, A. L.; Randall, R. J. Biochem. J., 1957, 193, 265-275.

9. Devaki, T.; Shivashangari, K.; Ravikumar, V.; Govindaraju, P. J. Ethnopharmacol., 2005, 101, 55-60.

10. Venukumar, M. R.; Latha, M. S. Indian J. Exp. Biol., 2004, 42, 792-797.

11. Nahed Saleh, S, Tamer, S A.; El-Rabeaie, R. M.; El-Sabbagh, H. S. J. Vet. Sci., 2018, 58, 1-14.

12. Pitt, O. Lysosome and cell functions Longman, London., 1975.

13. Manda, A.; Bishaye, A. Phy. Res., 1997, 11, 216-221. 